\title{
Russian-Gulf Relations: Reading in Present Interactions and Future Challenges
}

\author{
Ahmed M. Taher Hassan ${ }^{1} \&$ Norhan El-Sheikh ${ }^{1}$ \\ ${ }^{1}$ Faculty of Economics and Political Science, Cairo University, Cairo, Egypt \\ Correspondence: Ahmed M. Taher Hassan. E-mail: Ahmed81811@yahoo.com
}

Received: December 17, 2017

Accepted: December 26, 2017 Online Published: January 29, 2018

doi:10.5539/ass.v14n2p133

URL: https://doi.org/10.5539/ass.v14n2p133

\begin{abstract}
The current study tries to examine the Russian - Gulf relations, which witnessed the stages of convergence and divergence. The main factor governing these relations between the two sides is the regional and international conditions and interactions. There are a set of variables which have affected the Russian foreign policy making towards the Gulf region. The study aims to measure the impact of these variables on Russian-Gulf relations and to explore the future of these relations in light of these variables. To discuss this phenomenon and achieve the required results, systems analysis approach is adopted. The study concluded that the success of the Russian-Gulf rapprochement must be built on common direct interests with multiple directions and must not be built on the urgent international and regional circumstances. Thus, the relations between the two parties must transform from the relations of attitude and circumstance to the level of fixed strategic cooperative relations.
\end{abstract}

Keywords: Russian-Gulf relations, Internal Factors, the External Factors, Russia, Arab Gulf

\section{Introduction}

Moscow was the Arab World's destination in the 1950s and 1960s. The Arab countries were going to Moscow for diplomatic support, buying weapons, or gaining experience in various sciences and arts. For the Arab world, Russia was the international pole that provided support in various forms. However, Moscow focused, in its relations, on specific Arab countries such as Egypt, Syria, Iraq, Libya, Algeria and Yemen.

These relations accelerated until the late 1970s. However, the deceased President Anwar El-Sadat made a decision that Egypt will go to the West, specifically to the other pole, the United States. He said that $99 \%$ of the cards in the Middle East in the hands of the United States of America. Therefore, the level of relations between Egypt and Moscow has deteriorated. But Moscow's relations with other parties, notably with Syria, Iraq, Libya and Algeria, continued at a slower space.

With the election of Vladimir Putin as head of state, Russia's domestic and foreign policy has changed. This policy witnessed a significant improvement in role it plays in the international balance of power and its relationship with the Arab world. The Russian-Arab relations have been remarkably successful over the past 10 years, during which Moscow has re-launched its relations with its traditional allies in the region on new bases. The year 2000 marked the beginning of a new era in Russian policy towards the Arab region. Russia has become an essential player in the region's affairs and issues, which became increasingly acute and complex.

Needless to say, Russia's effective role in taking a clear position on many international and regional issues is due to the existence of a conscious leadership with a clear vision of its national priorities and its ability to implement and manage its consequences efficiently. This ability has been enhanced by the recovery of the Russian economy which helped to achieve increasing degrees of independence in its foreign policy.

As Russia was able to rearrange its situation in the region by the great efforts and successive visits of its readership, the wind of change blew, or as some call it Arab Revolution, which disarranged all papers. Thus, the rearrangement of these papers again became an urgent need.

There is no doubt that these developments will lead to the emergence of completely new regional variables. By the end of the transition, allies and rivals will be redefined, which will inevitably affect Russia's policy and its alliances in the region, given the fact that there are many visions to redraw the map of power and alliances. This matter will undoubtedly change the calculations of Russia and the data of its external decision-making. This change in itself is an important challenge facing Russian policy.

In this context, the Russian Gulf relations were witnessing a substantial and noticeable convergence, which 
manifested through the political visions and positions that are close to homogeneity. The same period witnessed a clear increase in the economic cooperation relations between the two sides, which led to the wide horizons in various fields of cooperation, especially those directly related to the expansion and activation of trade exchanges and the promotion of joint investments.

Accordingly, many questions arise: Does this activity represent a shift in Russian policy towards the Gulf region and its issues? What are the consequences of this transformation, both for Russia and its interests in the region or for the Gulf countries? How can the mutual benefit of both sides be realized, especially since Russian policy adopts a partnership approach in dealing with the countries and issues of the region?

To answer these questions, the study can be divided into three sections, as follows:

First: The factors governing Russian policy towards the Gulf States.

Second: Russia and the Gulf States: Areas of Cooperation and Challenges of Convergence.

Third: Russian-Gulf relations: reading future scenarios.

\section{The Key Factors of Russian Policy towards Gulf States}

There are a set of environmental variables affecting the making of a state's foreign policy. These variables help to shape and guide this policy. They are internal and external. The external variables relate to the case of international system which is effective by its structure and the nature of relations between its different actors, additionally the policies of action and reaction between the international actors, which are seen as the motivation to some external behaviors of the political units. The internal behaviors relate to the volume of internal variables which significantly impact on the guidance of foreign policy of the political unity. Therefore, identifying Russian foreign policy orientations towards Gulf region requires us to know the internal and external variables which impact on the Russian policy towards this region and its issues through two axes: the internal factors and the external ones.

\subsection{The Internal Factors}

There are factors governing the Russian policy towards the Gulf region. They are as follows:

\subsubsection{The Geographical Factor}

According to Napoleon Bonaparte's statement almost two centuries ago: "State policy lies in its geography", the geographical position is one of the constants of Russian politics (Gafal, 2008). Following the disintegration of the Soviet Union and the independence of its republics in the 1990s, Russia - the legitimate heir to the Soviet Union - moved away from the border which was occupied by the former Soviet Union. Also, the result of this disintegration was the loss of the space that the center in Moscow was ruled. United Russia having been characterized by the largest area geographically and census compared to the independent countries. The space of territory of Russia is 17,074,200, with a population of 146 million According to the latest estimates. The population of Russia back to different nationalities.

As a result of that the hereditary Russian state have no easy geographical port to the outside world which not seem safe geopolitically, only the non-indigenous northern space and almost permanently frozen.

Furthermore, the state suffers from internal conflicts and disputes. Some of these conflicts are ethnic and some other is religious. In addition to that, there are conflicts on its east, west and south borders. Therefore, we can say that Russia's geographical location is impregnable, and gives it significant strategic advantages. However, it is not the ideal location in terms of control and influence, where it had no access to the sea and it deprived of good ports overlooking valid warm seas (Brzezinski, 1999).

Thus, the geo-strategic importance of the Arab world emerges. The Arab region is characterized by the important strategic location between the three continents: Europe, Asia and Africa. Therefore, it controls over the most important world maritime lanes. This lanes starting from Bab al-Mandab and the Suez Canal which control the international navigation from Europe, Russia and united states to Indian ocean and the Far East, and down to Hormuz Strait which control the navigation between the richest world's region of oil production and its market in all the world. Furthermore, more than half of the world's oil reserves and nearly $30 \%$ of crude oil production is concentrated in this region, as well as the region controls the two Turkish Bosphorus and Dardanelles Straits which connect Black Sea with the Mediterranean one and it considers Moscow's gateway to warm water (Khirinkov, 2008).

\subsubsection{The Economic Factor}

The economic factor plays an important role in the formulation of Russian foreign policy (Laribi, 2014). Russia 
has carried out many economic reforms over the last ten years (Diab, 2002). It adopted the rules of the economy of the market and created the consumer's purchasing power. Also, it provided an appropriate environment to support medium and small businessmen and cut taxes. Therefore, the Russian economy has been recovered. It was able to be among the world's economy which was a source of attraction for both domestic and foreign investments. Due to the accelerated economic development and its multidisciplinary, the connection of Russian economy with the economies of Asia and Europe, and the expanded Russian capital beyond Russia's borders, Russian economy transferred to a new phase of integration with the global economy.

Despite of the achieved positive results during the past years, there are economic challenges faced Russia as a results of several factors, notably the decline of global oil demand, imposing west economic sanctions against Russia's economy. As a result of that, Russia started looking for other possible areas to restore economic recovery and to maintain the economic level and further export opportunities and attract foreign investment. Therefore, Russia sought to establish multi economic relations with all countries and increase exporting opportunities to earn foreign currency.

Thus, the gulf economies emerged to benefit from Russia's multiple advantages where it is characterized by economic and trading openness in many parts of the world. In addition, there was an investment environment encouraging capital and companies to invest where Russia has natural resources in many areas, and not only in the field of oil and gas (Al-Marhoun, 2006). Moreover Russia need to maintain what achieved over the past decade. It seeks to coordinate its productive policies with oil producing Arab countries to regulate the prices and maintain its level of decline especially Saudi Arabia as the largest oil exporter (Al-Namla, 2007).

\subsubsection{The Military Factor}

Russia has sought to strengthen its military position during pas years by upgrading its manpower and armament (Abdel Alim, 2015). This matter was evident in the assurance of the Russian political leadership. The past Russian President, Dmitry Medvedev, announced in September 2008 plans to establish an effective nuclear deterrent system by 2020. According to him, new nuclear submarines and space defense system must be established. With the arrival of President Vladimir Putin to power, these reaffirms continued. Putin raise the so-called strategic deterrence base. Putin suggested that this matter is to be done in parallel with enhancing Russia's international status, strengthening the political institutions and their economic capabilities, and securing the military and technological independence. Also, Putin signed the new military doctrine document on 26 December 2014. It considered an official statement about national security and its protection. The main foreign military threat to Russian security was the fight against religious extremism.

Accordingly, the role of the military factor highlights in directing the Russian policy towards Gulf region. Russia sought to double its armaments in general and nuclear weapons in particular. This weapon becomes an important matter whether in terms of Russian security or economic side through selling of weapons to earn foreign exchange to support its economy. Therefore,, Russia has sought continuously to be part of the armament equation in the Middle East, so that Middle East became one of the most important areas for Russia. Several Arab countries signed military agreements with Russia to buy weapons and the establishment of nuclear reactors for peaceful purposes. Not only that, but Russia was keen to sell its arms to some Gulf countries, such as Saudi Arabia, Bahrain and the United Arab Emirates.

\subsubsection{The political Factor}

In the context of Russia's efforts to restore its role globally since the end of the last decade, its trends have begun to change markedly in the Arab region. The Russian policy began to play an active role in some of Middle East' issues, taking into account that this role is not based on ideological considerations, as was the case during the period of the Soviet Union, but based on cooperative perspective dictated by considerations of interest and non-interference in the internal affairs of states. In the sense that the Russian role is looking for the rank of partner in all regions in which its interests exists.

The Arab region in general and the Gulf in particular are at the heart of these strategic interests. The Russian endeavor met Arab rapprochement in the light of two things: the first is the United States backing away from region affairs in general in the framework of the revision of its policies towards the region and its issues, and associated with American- Iranian rapprochement that produced agreement $(1+5)$ about the nuclear program of Iran and its impacts on security and stability in the gulf. The second is the nature of the Russian trends. Russia does not raise, in the context of international relations, any problems related to freedoms and human rights and do not interfere in the internal affairs of states. The Russian national security doctrine is based on faith in the role of the institutional powers of the state in the preservation of the national state. These matters are consistent with the current concerns of the Arab countries in general and the Gulf states in particular in view of the size of the 
risks and threats facing the countries of the region, especially fight against terrorism (Salama, 2012). In this regard, Saudi Arabia has a key role in reducing extremism in the Sunni party. In particular, Saudi Arabia is a necessary ally to fight this phenomenon. Russia is in dire need of a strong Sunni ally as Saudi Arabia because of the Muslim population in Russia (Al-Husseni, 2015).

\subsection{The External Factors}

Russia has played a prominent role in every international and regional situations and issues related to the Gulf region. It intervened in the regional policy of the region through its political and economic tools directly the military tool indirectly. Russia adopted this policy due to a number of external determinants where the international order and the Middle East have witnessed significant transformations.

Thus, there are two types of factors pushed the Russian state to reorient its policy toward the region and to play an important role in its crises:

\subsubsection{Transformations at the international level}

When President Vladimir Putin came to power in the early of current century, Russia has restored its role. It began to occupy a more advanced position in the international system, which reflected on its role in the Arab region. Russia has oriented towards the Arab region, especially the Gulf region to compensate its losses due to its tense relations with European countries. The Arab region was an appropriate market for recovering the Russian economy through multiple arms deals and attracting more investments from the Gulf States into Russian territories. Russia had benefited from the decline of the American role in the Arab region and established trust bridges with the Arab States. The US- Arab relations have declined due to policy adopted by US in managing the files of the region. For example, the US failed to manage the file of the Arab- Israeli conflict (Brown, 2014), and failed also in Iraq, which resulted in many terrorist organizations such as Al- Qaeda and ISIS (Al- Juhaini, 2014). In addition, due to the Arab Revolutions, the US failed to maintain the stability of regimes with which it has long relations over the past decades. In addition to that, confidence between the US and the leaders of the Gulf Cooperation Council has been declined due to the signing of the nuclear agreement with Tehran without taking the Gulf concerns into account. In this vein, it should be noted that change in American policy comes within the concept of "New American Strategic Security". This concept includes the direction of the US towards the regional empowerment of Iran. The following indicators confirm this matter (Turki, 2015):

- A statement of President Barack Obama saying: "We look forward to Iran as an active regional power".

- The deliberate American disregard for full Iranian control over southern Iraq and the transformation of Iraq into sectarian blocs, making Iraq the main access to the main Gulf security in the future.

- The American position on the future of the Syrian crisis where the US wants to manage this crisis through the Iranian gateway. Under this position, the Shiite Crescent project, as an Iranian project, has been transformed into a Shiite sectarian triangle run by Iran. This triangle includes the geography of three countries, which are Iraq, Syria and Lebanon.

This means that Russia is playing on the point that the US has lost the confidence of its allies. To achieve this, it has taken practical steps aimed at supporting its engagement with the Arab world employing many mass media. Such mass media aim at changing the view of the world about Russia. Thus, it has changed many of the media leaders and departments such as the Russian New Agency, Novosti, and the radio broadcasting station, Voice of Russia. Furthermore, it has opened a new international news channel (Russia Today), which is broadcasting throughout the day in the Arabic language. It has also launched the project of beyond news, which publishes the issues related to Russia around the world. Additionally, the Russian International Foundation has been working to disseminate the Russian language and culture throughout the world, particularly in the Arab world, through cultural centers (Ddiniski, 2014).

\subsubsection{Transformations at the regional level}

Since the beginning of the third millennium, the Arab region has witnessed a series of changes and transformation which made international actors eager to reconsider in their orientation towards the region and its issues. Therefore, there are four determinants occurred at the regional level, which are:

\section{1-The US occupation of Afghanistan in 2001:}

Russia supported initially the US war. This support came in abide to include its war against separatists in Chechen among goals that the international coalition is striving to achieve in its fight against terrorism. This goal has been achieved when most European countries were convinced that the Chechen war was an internal Russian problem (Al- Asfahani, 2002). Furthermore, Russia believed that the US presence in Afghanistan is in the 
interest of it for eliminating the common source of threat, namely terrorist organizations such as Taliban and AlQaeda. It is true that Russia did not provide direct support for this presence, but it has supported this presence morally because it does not reject this occupation (Abdel Hamid, 2009).

\section{2-The US occupation of Iraq in 2003:}

It represented a new transformation in the international system. Therefore, the region looked like the base from which rules of the new world system would be launched according to the interests of the great powers. The race between the major international powers has become the most prominent role in the Arab region. Therefore, Russia has sought to find a position in forming the great international poles. To achieve this, it moved in the Arab region economically, politically, militarily in order to become an essential partner of the Arab states.

3-Arab Revolutions and changes of Regional Reality:

The Russian position from the Arab Revolutions was different according to its strategic interests. Russia stressed that these events damage Russia's interests in the region being come in the framework of the US- backed colored revolutions. Russian President Medvedev said at the end of April 2012 when he was talking about developments in the Arab world: "the Arab Spring will end and the cold Arab Autumn will come. Radicals will come to power, and it will be much harder to work with them", (Kosach, 2016). In sum, Russia has adopted three orientations towards these events. First, it has remained silent about events in order to be mature, and those in power have been displaced, as happened in Tunisia and Egypt. Second, it has adopted the position of neutrality or follow up, which reached the level of slow as happened in the case of Yemen, Bahrain and Morocco. Third, it has adopted clear positions. The degree and style of these positions varied as happened in Libya and Syria where positions of support have been clearly expressed to the governing authority in Libya and Syria, with the difference of the pattern and degree of support (Said, 2015).

4-Continued stalemate in the Arab- Israeli peace process:

In the shadow of these escalated circumstances, Israel continued its plans aiming to liquidate the Palestinian cause. Israel has exploited these conditions to assert its army strength and its ability to protect their security. This explains the reasons for its war against Gaza in 2012 and 2014 and its recent military operations against Hezbollah. Given the escalation of Israeli - Palestinian tensions and the Israeli intervention in Syria, the way might be paved to the outbreak of a large- scale war in the region in the shadow of preoccupation with other issues. Thus, the Russian interests might be threatened, which force Russia to engage in this war in case of its expansion (Asaileh, 2015). It became involved in the Syrian crisis to support the regime of President Bashar AlAssad.

\section{Russia and Gulf States: Areas of Cooperation and the Challenges of Rapprochement}

Gulf-Russian relations have witnessed an increasing growth since Russian President Vladimir Putin came to power in 2000 as part of his vision on the joint Arab- Russian action aimed at achieving the Russian endeavor to regain its global position. This rapprochement remained confined to the economic, technical and military aspects. However, the political sphere has been the point of disagreement between the two parties, specifically in the aspects of the Russian- Iranian cooperation, as well as the Russian- Israeli cooperation. In addition, Russia's views are diverged with the Gulf situation, on some the region's issues, as in the Syrian and Yemeni crises.

Thus, the most prominent features of the Gulf- Russian cooperation can be monitored in several indicators as follows:

\subsection{Cooperation in Energy (Oil and Natural Gas)}

Russia is one of the rich countries in energy sources, namely oil and natural gas. Russian oil reserve occupies the seventh rank after the Gulf States and Venezuela. The oil reserve estimated at about 60 billion barrels, representing $4.6 \%$ of the world reserve. Also, it is ranked second as the world's largest oil producer and exporter after Saudi Arabia, estimating at about $40 \%$ of the global total of oil exports.

In this vein, Russia seeks to coordinate and cooperate with Arab countries, especially oil and natural- producing countries in order to achieve both Russian and Arab interests. Cooperation and coordination in the sector of energy come on the top priorities of Russian policy in the Arab region. The sector of energy is one of the key eras in which Russian- Arab interests converge (El- Sheikh, 2017). This coordination is carried out through three basic frameworks. First, maintaining the stability of the oil market. Second, the Russian investments in the Gulf oil sector. Third, creating a forum for gas- exporting countries.

\subsection{Increasing the Volume of Mutual Investments}

The mutual investment between Russia and the Gulf States is one of the forms of cooperation between the two 
sides. However, the volume of mutual investment is still low compared to the volume of the Gulf capital or the capacity of Russian economy. According to some estimates, the total volume of external Arab investment is more than $\$ 1200$ billion (Rifai, 2014). The Arab investments in Russia remained limited compared to the volume of external Arab investment in general and in the Gulf in particular. However, the Gulf investment was the most important share for the Russian Direct Investment Fund, amounting at $\$ 10$ billion. Investments are distributed as follows: UAE pumped \$7 billion, which is distributed between Abu Dhabi Finance Department (investments estimated at \$2 billion, Kuwait pumped, through the Kuwaiti Investment Authority (KIA), \$500 million, and Qatar pumped \$2 billion through Qatar Investment Agency.

\subsection{Cooperation in the Field of Nuclear Power}

Russia has contributed to the assistance of many Arab countries in constructing and developing nuclear research centers and training of scientific cadres in this field. This cooperation has increased due to the growing trend of global reliance on nuclear energy. Some studies have indicated that the demand for nuclear energy is some expected to grow. A recent edition of reference data bulletin issued by International Atomic Energy Agency (IAEA) for the period from 2012 to 2030 indicated that the global demand for atomic energy is between 2.1 and $5.0 \%$, and the demand for nuclear energy in the Middle East and East Asia will range between 10.4 and 14.7 \%.

In this context, the majority of Arab States have moved towards nuclear energy and its use for peaceful purposes. This matter enhanced the Arab- Russian rapprochement in this field because the vision of Russian partner concerning the deployment of nuclear technology for peaceful purposes stems from a pure economic vision and does not place any political restrictions on cooperation with any state in this field, as long as it has been done in public and under the supervision of the International Atomic Energy Agency.

Thus, some Gulf States have sought to conclude agreements with the Russian side with regard to the construction of their nuclear reactors, notably the following agreements:

- The UAE- Russia agreement on 17 December 2012. This agreement stipulated the cooperation in the use of nuclear power for peaceful. It entered into force on 21 August 2013. It covers all aspects of nuclear energy, from uranium extraction and enrichment and fuel production, to the establishment and delivery of nuclear energy reactors, as well as the preparation of cadres and joint scientific research.

- $\quad$ The Saudi- Russian agreement in June 2015. It is stipulated cooperation in the use of nuclear energy for peaceful purposes. It is noteworthy that the agreement was signed by the director of the Russian Ross Atom Company, Sergei Kiriyenko, and by the head of King Abdullah City for Atomic and Renewable Energy, Hashim Bin Abdullah Yamani.

\subsection{Cooperation in the field of Space}

Space is a wide area for Russian-Gulf rapprochement. As through Russian space rockets, a number of Arab countries have joined the club of countries that have satellites in orbit for various purposes, and Saudi Arabia leads the list of these countries. From 2000 to the present, Russian rockets have put into orbit 13 Saudi remote-sensing satellites, such as Saudi Sat, SaudiSat-3, Saudi Comsat, and Arabsat-B4. Arabsat-B4 is attributed to the Arab satellite Communication organization-ARABSAT (Saudi Arabia), which provides service in the field of television digital broadcasting and telephone communications, as well as the provision of access to the internet for the people of the Middle East and North African countries. Through these devices, solar imaging and other information are collected for the communications, agriculture and environmental protection sectors in the kingdom. In 2008, the Russian Space Agency "Roskosmos" and the Russian Ministry of Foreign Affairs worked with Saudi Arabia to establish the correct contractual framework for the agreements: On cooperation in the Exploration and use of outer space for peaceful purposes, and the joint development and use of the GLONASS network (Mukhtar, 2015).

On the sidelines of the visit of Crown Prince Mohammed bin Salman bin Abdul Aziz to Russia in June 2015, Russia and Saudi Arabia signed a joint memorandum of intentions in the field of space. This memorandum was based on several steps that have been established for the cooperation of the parties in this area. The two parties have already signed a bilateral convention in the field of air communications and atomic technology of the space invasion for the peaceful purposes during Russian President Vladimir Putin's visit to Saudi Arabia in 2007.

\subsection{Cooperation in the Military Field}

Russia has sought to open new markets to export its arms to the Arab Gulf States to represent an addendum to its conventional arms market with many Arab States. The past period has witnessed Russian-Gulf cooperation in the military field, notably: 
1-Signing an agreement of Cooperation in the military and technical fields between Russia and the Kingdom of Saudi Arabia in 2008.

2-Signing an agreement to enhance military and technical cooperation between Russia and the Kingdom of Bahrain on 19 May 2015.

However, despite this Russian-Gulf rapprochement, there are challenges that stand out in the divergent views of the two sides on some common interest issues, particularly those relating to the region. The most controversial issues between the two sides are the following:

\section{Russian-Iranian Qualitative Relations}

Needless to say, the intersection of interests between Moscow and Tehran is necessarily matched by the intersection of Russian-Arab interests. If that managed as required, more change will take place in Moscow's orientations in some crises in the region to support the Arab position, especially since the interests between Russia and the Arab States are far greater and broader than interests between Russia and Iran. By excluding the possibility of an alliance between Moscow and Tehran, Arabs can change the Russian priorities and positions, provided that the Arab countries understand the Russian interests in the region on the one hand, and determine their own interests on the other (El-Sheikh, 2015).

It is also important that the Arab States in general and the Gulf in particular understand that Russia will not consider the Arab States as an alternative to its relations with Iran. Russia believes that maintaining stability in the region depends on the will of a group of actors in the region and beyond, and that consensus and understanding between those actors is the decisive factor in achieving the regional stability.

Therefore, with expressing its readiness to mediate in this regard, Moscow raised the issue of establishing a regional security system in which Iran participates with the region states or some of them. Russian Foreign Minister Sergei Lavrov announced in February 2014 that Moscow is ready to contribute to the normalization of relations between Iran and Gulf countries (El-Sheikh, 2014).

\section{The Russian position of Decisive Storm in Yemen}

Russia has adopted a stance against the Arab alliance, which was formed under the leadership of the Kingdom of Saudi Arabia and included 10 Arab states to counter the control of the Ansar Allah on the Yemeni State following its control of the capital, Sanaa, on 21 September 2014, forcing the Yemeni President "Abdrabbuh Mansur Hadi" and his government, which was headed by "Khaled Bahah" to resign in January 2015. They have issued a constitutional declaration that aligns their position on Feb. 6, 2015, before the Yemeni president's flight to Aden. Russia refused to consider what happened in Yemen a coup by the Houthis on legitimacy. Russia described this matter as a maneuver on their part to raise the limit of their demands in the framework of the ongoing political process in the country. Moscow indicated that the Houthis is a political faction with a strong presence that cannot be ignored, but must be contained as a partner in the political process in order to maintain stability in the state (Saad, 2015).

Therefore, Russia has opposed from the Arab coalition, which has worked under the "Decisive Storm". Russia has expressed its clear concern about what is happening and its future repercussions on the stability of the region. Russian President Vladimir Putin stressed the importance of an immediate cessation of hostilities in Yemen and the need to activate efforts, including the efforts of the United Nations, to develop peaceful solutions to the Yemeni conflict and to launch a broad dialogue with the participation of all political and religious powers in the country.

However, Russia is keen to achieve its interests with all parties, especially the Gulf States. In particular, it recognizes the importance of Yemen to the Gulf. Russia has adopted a balanced position on the conflict. Thus, it did not want to abort security council resolution 2216 of 14 April 2015, in accordance with Chapter VII of the Charter of the United Nations by abstaining from voting.

\section{Syrian Crisis}

The Russian and Gulf position on the Russian role in the Syrian crisis of supporting Bashar al-Assad regime has diverged. This support reached the level of military intervention. The Gulf States opposed this support and intervention, with the exception of the Sultanate of Oman where its position was closer to silence and neutrality. However, we could even observe a discrepancy between the five Gulf States. Saudi Arabia, UAE, Qatar and Bahrain have expressed strong opposition, while Kuwait has expressed a lesser degree of opposition.

Therefore, we can summarize the points of the Russian-Gulf divergence on the Syrian crisis in two main points:

1-Who is the enemy? At a time when the active Gulf States in the crisis, namely Saudi Arabia, Qatar and the 
UAE, believe that the main enemy includes the Syrian regime, the extremist political organizations, namely, ISIS and Al-Qaidah, as well as Shiite organizations supporting the regime. While Russia believes that any militant organization or faction fighting 'Bashar al-Assad' regime is an enemy, taking into account that the Free Syrian Army (FSA), which enjoys the support of the Gulf States, is not a terrorist organization from the Russian standpoint. However, Russia believes that the FSA should be part of the political solution. At the beginning of its strikes, Russia targeted some of the FSA positions. This is confirmed by the Kremlin spokesman, "Dmitry Piskov" saying that: "The aim of the air strikes is, in fact, to help the Syrian armed forces in their vulnerable positions, with no exceptions.

2-The future of Syrian President Bashar al-Assad and how to end the conflict? At a time when the Gulf States believe that there is no future for Syria under the presence of Bashar al-Assad and that any political transition must step down 'al-Assad' from the power. The only disagreement between the parties is related to the need for the departure of Syrian President Bashar al-Assad and the stage at which he must be deported. According to Adel Al-Jubari, Saudi Foreign Minister, following the Vienna-1:" while Moscow believes that "Bashar Al-Assad" is part of the solution and whether or not to remain in power should not be raised on the negotiating table" (Naumkin et al., 2012).

\section{Future Scenarios}

The course of Russian-Gulf relations has raised the question of the scenarios of their future prospects in the context of international and regional transformations taking place in the world and the region. Three scenarios can be distinguished in this context, as follows:

\subsection{Maintaining the Status quo}

According to this scenario, the parties' relations remain based on the current situation, combining the possibility of intensifying their relations under the Russian quest for creating positions of influence in the region, and the possibility of isolation from this site due to some difficulties and constraints encountered. According to this scenario, it is also expected that the Gulf region will not receive a clear and advanced priority within the overall strategy of Russian foreign policy. The movement of its policy in the region remains linked only to achieve the elements of this strategy aimed at attaining the international standing to which Russia aspires under a multi-polar world.

Therefore, according to this scenario, Russia will seek to deal with the majority of the region's issues through continuous communication with all concerned parties at the same time. It aims to adopt a policy of compromise without prejudice to the balance in the region on the one hand and preserve its vital interests on the other. Proponents of this scenario believe that Russia finds the role of mediation acceptable, allowing it to play an influential global role, especially during negotiations. This role also enables it to take a good position to manipulate the tensions between the various parties in favor of its national interests. For example, for the Syrian crisis, hesitation shown by Washington about Syrian events in the face of Russian intransigence showed the weak and powerless image of Washington before the international community and American public opinion. Damascus's agreement to disarm and destroy chemical weapons has given Moscow new powers to be used in the process of reviving Russia's global role and safeguarding its national interests and international standing. This was accompanied by Russia's presentation of a good image different from the stereotype in the game of nations, the image of an ally fighting with its ally in a single trench, while American pragmatism suggested leaving the losing ally to find his destiny.

This picture can certainly contribute to changing the pattern of alliances in the Middle East since the First World War so far.

In this context, the Russian vision of its interactions with the Gulf issues and its crises remains unclear. The opportunities for its expansion in the region remain linked to the dynamics of the internal interactions of these states on the one hand, and the nature of American orientations and its relations with the region states and their issues on the other. This could be either a hostile climate to Russia's policies and its presence in the region, or welcome to it, which pave the way to its further presence and interaction with the region's issues.

\subsection{Decline and isolation in Russian-Gulf relations}

According to this scenario, despite the numerous achievements in the field of Russian foreign policy towards the Gulf region and its issues, it has witnessed also many failures, as well as a range of constraints that may lead Russia to the downturn from playing important roles in the region, and may even be moved towards isolation from regional and state issues.

The Proponents of this scenario believe that Russia had no role or a clear achievement in some issues, including: 
- The US occupation of Afghanistan and Iraq after the events of 11/9. Russia went to support the United States in its declared war against terrorism in response to the American approach of "who is not with us, he is against us (Bahaz, 2014).

- The Iranian nuclear file. There was a contradiction in the Russian role. While it was delaying the imposition of sanctions on Tehran, it then returned to accept it, a scenario that repeated four times.

As a result of how Russia deals with regional issues, the problem of trust has been raised between it and some Gulf States, which may prevent any attempts to enter into strong partnership or alliance with it.

Not only this has been the case, but the Russian role in the region faces several constraints. The economic conditions inside Russia that limit their external movement, such as low oil prices, low levels of investment and the effects of all on the domestic circumstances (Kliment, 2014) which may limit resources and capabilities directed to its foreign policy, where priority is given to Soviet neighbor States. Russian arms exports also have declined under the Russian deficit to enter some of the world's major conventional arms markets, such as the Arab Gulf States. They rely on American and Western arms, especially in the light of the relative decline in technological level for Russian military products compared to their American and Western counterparts (Mahmoud, 2007). The Stokolhm International Peace Research Institute (SIPRI) noted that the United States is the largest exporter of arms in the past five years, which reached $31 \%$ of the total arms sales in the world, while Russia occupies second place at $22 \%$. In this context, the Middle East's share of Washington's sales has reached about $32 \%$, which means practically that the United States will continue to be the largest supplier of arms to both the world and the region.

In addition, there are other factors relating to the positions of the region states in their relations with Russia, which are varied according to the specific interests of each state. So far, the Gulf States have not considered Russia as a substitute for the United States, especially in the light of the American eagerness to counter any increase in the Russian presence in the region. Furthermore, the Russian vision of its role in the region based on cooperation with the United States, not confrontation or conflict on the other (Rajab, 2014). Also, the economic downturn that has hit Russia because of the decline in oil prices which has continued to decrease the impact of its role in the region.

Therefore, the proponents of this scenario conclude that the prospect of a downturn or isolation in Russian-Gulf relations is still in place, and is expected to prevail in the near term, in the light of Russia's internal problems, and the disruption of its positions on the issues of the region. Additionally, the US has influence in the region and cannot easily relinquish it to other international powers.

\subsection{Continuation and Intensification of Russian-Gulf Relations}

According to this scenario, Russia has made a range of achievements and successes that gave it a strong impetus to its foreign policy, after a period of decline at the international and regional levels, including the loss of influence even in the most affected areas of its national security. However, its internal success since President Vladimir Putin took office at the beginning of the third millennium, Russia has regained much of what it lost and have come back to play active roles and take clear positions on many international and regional issues (El-Sheikh, 2007). The Arab region in general and the Gulf region in particular are part of this Russian return. The relations between the two sides during the last decade have witnessed more rapprochement and cooperation similar to those of the 1950s and 1960s. This evolution in relations would contribute to the development of the economic, technical and military partnership in the coming period, indicating the continuation and intensification of these relations, especially as Russia's emergence as an important and major actor in the region. The Saudi-Russian rapprochement, as well as the deepening of Russian cooperation with several Arab parties, may give indications that the region is undergoing a shift in its relations with Moscow and Washington, and hence the balance of world powers.

According to this scenario, there are broad prospects for cooperation and partnership with the Gulf States in the fields of nuclear energy, the development of industrial infrastructure and the technology space. The Russian policy movement is also expected to continue its efforts to hold more arms deals to the region states, as well as the Russian pursuit of coordination to build strategic alliances and to enter into partnerships with regard to oil production and prices (Bahaz, 2014).

This trend is underscored by the fact that there are factors driving the increase of Russian influence in the region in the coming period, which can be summarized as follows:

1-Russia has regained its position as a major power. This is accompanied by a change in the balance of world powers. Russia has restored a large part of its international standing and has taken a clear stance on many 
international and regional issues. It has successed in curbing the American role and impeding its movement in many situations, notably the Syrian crisis, which has earned it the respect and confidence of states as an important and active partner.

2-The recognition of Russia of the strategic importance of the Arab region, particularly the Arab Gulf region, because it represents an economic, financial and commercial power on the one hand, and it is an access to more than $50 \%$ of the world's oil supplies on the other.

3-Russian-Gulf interests have become more intertwined, which has made these states go towards Russia (El-Sheikh, 2014).

4-The geographical factor and adjacent borders impact positively on strengthening relations.

5-The social structure of the Russian people is a mixture of predominantly Christian Orthodox and Islamic civilizations, and the two civilizations came to Russia from the Arab world.

6-Russian-Arab relations are free of any wars or conflicts in history, since Russia has never been a colonial power in the region during the Soviet era, and there are no major problems in this relationship at this time (Naumkin, 2015).

Additionally, this latter scenario is the closest to be achieved in the foreseeable future. But the important question is, if this is the scenario at hand, what are the ways and mechanisms that can contribute to the development and advancement of the parties' relations?

The answer is that it is important to work to strengthen the Gulf-Russian relations and to push them towards greater rapprochement to the benefit the two parties in accordance with the "win. Win" approach. To achieve this matter, a set of measures must be followed in the economic, political, cultural and scientific fields, which are:

First- In the Economic Field, it is important to:

1- Activate the Russian-Gulf cooperative structures to maximize the use of the cooperative potential between them, particularly in the economic and technical fields.

2- Deepen and expand the scope of Russian-Gulf cooperation in oil and natural gas production, not only on the volume of production and price control, but also on the exploitation of Russian technology in research, exploration and production development.

3- Develop a comprehensive information base on the Russian market in order to understand the needs of this market, which has a broad capacity (El-Sheikh, 2007).

4- Activate commercial and financial cooperation between the two parties.

5- Eliminate the obstacles to expand the climate of mutual investment, particularly those relating to national laws and regulations, current commercial practices and domestic traditions and specificities.

Second-In the Political Field, it is important to:

1- Establish a cohesive Gulf diplomacy, capable of effectively dealing with international confrontations that are ravaging the region's affairs and issues.

2- Develop the Gulf discourse in dealing with the new international issues, interactions and balances in which Russia has become an active player. There is also a need to develop the Russian discourse in its dealings with the Gulf States and to understand their apprehensions and issues.

3- Support and strengthen the Russian role in the region in order to promote it as an international power parallel to American power.

4- Establish a common basis through parliamentary representation to develop appropriate legislation and legal foundations that serve the development of relations between the two parties.

Third- In the Cultural and Scientific Fields, it is important to:

1- Establish an Arab-Islamic scientific center for the study of Arabic and Islamic scientific manuscripts in Russia.

2- Activate the role of Non-Governmental Organizations (NGOs) and parliaments in order to build bridges of cooperation between the two parties (Hamza, 2010).

3- Seek to a media convergence where media play a role in rapprochement and interaction (Mutamad, 2009).

4- Activate translation from Russian to Arabic and vice versa by establishing publishing houses for translation. 
5- Benefit from the presence of about 25 million Russian Muslims who represent a strategic depth for the Arab world.

6- Benefit from the Arab immigrant community in Russia because they have enormous potential that can contribute to solving many problems of Arab-Russian relations.

\section{Conclusion}

In conclusion, the success of the Russian-Gulf rapprochement must be built on common direct interests with multiple directions and must not be built on the urgent international and regional circumstances. Thus, the relations between the two parties must transform from the relations of attitude and circumstance to the level of fixed strategic cooperative relations (Turki, 2015).

\section{References}

Abdel Alim, A. (2015). Global Race: The Future of the Arms Industry in the World 2030. Retrieved from http://www.futurecenter.ae/report.php?report=493.

Abdel Hamid, A. M. (2015). Russia's Restoration of the International Pole Position: Crisis of the Transitional Period, Al Jazeera series. Retrieved from http://america.aljazeera.com/articles/2015/9/2/the-us-confronts-arussian-push-for-the-arctic.html

Al-Asfahani, N. (2002). Dimensions of the Russian-American Rapprochement after the Events of September 11. Al-Siyassa Al-Dawlia Journal, (147), 118-121.

Al-Husseni, H. (2015). The Saudi-Russian Rapprochement put a limit for Iranian Expanding. Middle East Newspaper, No.13358.

Al-Juhaini, D. (2014). Change in the Strategic Map of the Middle East. Trends of Events Journal, (2), 86-88.

Al-Marhoun, A. Z. (2006). G-8 in the Russian calculations. Riyadh newspaper, issue 13892. Retrieved from http://www.alriyadh.com/169320.

Al-Namla, S. (2007). Event Mask, Russian-American Relations. Riyadh Newspaper, issue 14316. Retrieved from http://www.alriyadh.com/277405.

Alternative Framework: How Russia succeeded in activating weapons diplomacy in the Middle East. Regional Center for Strategic Studies, 15/7/2015. Retrieved from http://www.rcssmideast.org/Default.aspx/Article/ 3614/Sections.aspx?SectionId $=5$

Asaileh, S. (2015). Will the rules of the Game Change with Palestine and Hezbollah? The Israeli Threat in a New Phase. Al-Siyassa Al-Dawlia Journal, (201), 105-108.

Bahaz, H. (2014). A Study of Russian Political Behavior towards Arab Revolutions. African Journal of Political Science. Retrieved from http://montada.echoroukonline.com/showthread.php?t=290995

Berman, I. (2014). The Great War Again: Today's Global Tensions Echo the Lead-up to World War: Could this be the end for our world order? Retrieved from http://www.usnews.com/opinion/blogs/world-report/2014/ 07/25/ukraine-russia-the-middle-east-and-the-return-of-world-war-i?int $=9 \mathrm{a} 4808$

Bogomolov, O. T. (2000) Russia in Facing the Challenges of the Twenty-first Century, International Journal of Social Sciences, (163), 135-137.

Brown, N. J. (2014). What the Gaza war means for The Middle East? Carnegie Endowment for Int. Peace. Retrieved from http://carnegieendowment.org/2014/07/28/what-gaza-war-means-for-middle-east-pub-56267

Brzezinski, Z. (1999). Great Chessboard: the American Priority and its Geostrategic Requirement, translated by Amal Al Sharqi. Amman: Al Ahlia for Publishing and Distribution.

Diab, A. (2002). Russia and the West: From Confrontation to Participation, Journal of International Politics, (149), 173-176.

Dolinski, A. (2014). Double Policies: Russia Is Facing the Ukrainian crisis with Soft and hard power. Trends of Events Journal, 1(2), 80-83.

El-Sayed, I. S. (2015). Between terrorist Expansion and Iranian Expansion: Russian Politics and Middle East Security. Al-Siyassa Al-Dawlia Journal, (201), 114-117.

El-Sheikh, N. (2011). Fixed nterests and New Data. Russian policy towards the Region after the Arab Revolutions. Al-Siyassa Al-Dawlia Journal, (186), 112-115.

El-Sheikh, N. (2014) Challenges and Constraints: Limits of Russia's Role in the Middle East. Afaq Siyasia 
Journal, (2). Retrieved from http://hcrsiraq.org/720

El-Shiekh, N. (2007). Russian politics in the Arab Region: Starting Points and the Limits of the Role. Sheo'an Arabia Journal, (129), 82-98.

El-Shiekh, N. (2007). Russian-Euro-Atlantic Relations between National Interests and Strategic Partnership. Al-Siyassa Al-Dawlia Journal, 46-54.

El-Shiekh, N. (2014). Thoughtful Alliance: The determinants of the consensus between Iran and Russia. Al-Siyassa Al-Dawlia Journal, (196), 95-98.

El-Shiekh, N. (2015). Russian-Iranian Relations: It Is Tactical or Strategy. J. of Views on the Gulf, (99), 91-93.

Gafal, A. (2008). Change and Continuity in the Strategic Importance of the Arabian Gulf Region. Dar Houma.

Hussein, A. S. (2014). Russian policies towards the Middle East. Democracy Journal. Retrieve from http://democracy.ahram.org.eg/News/795/Subscriptions.aspx.

Khirinkov, A. (2008). Russian Interests in the Red Sea and Horn of Africa. J. of Middle Affairs, (128), 75-81.

Kosach, G. (2016). Russian-Saudi Relations. Retrieved from https://www.rbth.com/world/2016/03/11/despitesyria-russia-works-with-saudi-arabia_574791

Laribi, K. (2014). Russian Foreign Policy towards the Middle East after the Events of 11 September, 2001 (Unpublished master's thesis). Baskra, Algeria: Mohamed Khaider University.

Mukhtar, M. (2015). Russian-Saudi Relations over the ages.

Mutamad, A. (2009). Russia and the Arab World in the Shadow of Global Transformation. Working Paper presented at: "Arab-Russian Relations Forum". Dopha: Al-Jazeera Center for Studies.

Naumkin, V. (2015). Did Moscow's 'air defense' diplomacy land Saudi deal? Retrieved from www.almonitor.com/pulse/originals/2015/06/moscow-diplomacy-middle-east-air-defense.html\#ixzz3rJu7PLUd

Naumkin, V. et al. (2012). Transformations in the Arab World and Russian Interests: Analytical Report of the Forum of International Dialogue. Moscow: Valde.

New Military Doctrine: NATO Expansion - One of the Biggest Threats (2014). Voice of Russia. Retrieved from http://arabic.sputniknews.com/arabic.ruvr.ru/news/

Rajab, E. (2014). Russian Project: Foreign Policy Challenges of Moscow in the Middle East. Cairo: Regional Center for Strategic Studies. Retrieved from http://www.rcssmideast.org/Author.aspx?AuthorId=11

Rifai, N. (2014). Limited Balances: An Analytical Vision of the Developments of Inter-Arab Investments during 2014. Economics and Business Report. Retrieved from http://www.dcss-center.org/business_economy_ report/arc.php?rw=267

Russia plans to modernize its nuclear system. (2008). BBC website. Retrieved from http://news.bbc.co.uk/hi/ arabic/world_news/newsid_7638000/7638973.stm

Russia Today. An overview of the economy in Russia. Retrieved from http://www.rtarabic.com/russia/10441/

Said, A. (2015). Beyond the Arab Spring: Regional Security in the Middle East. Al-Siyassa Al-Dawlia Journal, (201), 46-48.

Salamah, M. (2012). Expanding Options: Saudi Opening to Russia: Is It Strategic or Tactical Orientation? Cairo: Regional Center for Strategic Studies. Retrieved from http://50.7.137.27/Sections.aspx?SectionId=2

Saunders, P. J. (2015). Will Russia's economic decline affects its Middle East influence?

Stopping the Stalemate and Launch Readiness. Sputnik News Agency. Retrieved from http://arabic.sputniknews.com/arabic.ruvr.ru/2015_01_23/282376369/

Suchkov, M. A. (2014). What's behind Russia's Mideast strategy? Retrieved from http://www.al-monitor.com/pulse/en/originals/2014/11/russia-mideast-strategy-behind-scenes.html

Turki, M. (2015). Motivation and Indications in Saudi-Russian Rapprochement. Al-Jazeera Center for Studies. Retrieved from http://studies.aljazeera.net/en/

\section{Copyrights}

Copyright for this article is retained by the author(s), with first publication rights granted to the journal.

This is an open-access article distributed under the terms and conditions of the Creative Commons Attribution license (http://creativecommons.org/licenses/by/4.0/). 